\title{
An Analysis on Significant International Issues of US-Turkey Relations during 2001-2019 Period
}

\author{
Dr. Hakan ÇORA* \\ *Asst. Prof., Istanbul Okan University, Faculty of Business and Administrative Sciences, Business Administration Department. \\ ORCID: 0000-0001-5780-549X - Email: corahakan@gmail.com
}

\begin{abstract}
Following 9/11, the United States of America set new goals such as the global fight against terrorism, intervention in countries supporting terrorism, and the provision of democracy. It created a common threat perception and implemented policies of cooperation with other western states. Turkey became an essential ally for the US as it has a Muslim identity and has close ties with the Middle East, which the US wants to shape due to the common terror perception. However, while the US-Turkey relations continue positively in general, it witnessed some unforgettable developments. We can exemplify the events that directly affect the security dimension of Turkish-US relations following the 9/11 as following: March 1 Memorandum, the raid by US soldiers with peshmerga to the outpost that is used by Turkish Special Forces, US support to PKK, April 24 statement on Armenian Issue, Wikileaks documents along with US policy toward Turkey, extradition of Fethullah Gulen, leader of FETO/PYD terrorist organization, the trial of Pastor Brunson, S-400 crisis, Syria cross-border intervention.
\end{abstract}

Keywords:

US - Turkish Relations, International Relations, US Foreign Policy

Article Received: 18 October 2020, Revised: 3 November 2020, Accepted: 24 December 2020

\section{Introduction}

Turkey's recent relations with the US have evolved to constitute a new partnership model. Because of the understanding, which is defined as a strategic partnership and is no longer filled but also based on the US's unilateral action, it has difficulty finding an explanation as a partnership. In contrast, the model partnership attitude reveals itself as a new attitude for Turkey that is ready to listen to and assess the other party's suggestions and opinions and expresses that it has a vision and voice breaking off narrow visions. Per the definition of Barack Obama, the model partnership is a partnership model based on the common ideals and values of the two countries: freedom of belief, human rights, the rule of law, and democracy, which are not limited to security (Simon, 2019).

Recently, problems have arisen between the US administration and Turkey about many issues. We experienced the Iraq issue followed by the YPG problem and then, treacherous July 15 coup attempt, the non-extradition of Fethullah Gülen, and rights and freedoms problems. Trump barely mentioned Turkey during his election campaign. He also emphasized that Turkey could terminate DAESH terrorist organization.

The suppressing of the July 15 coup attempt with the people as a whole influenced the world and the US president. Trump expressed that he admired those who prevented the coup attempt. However, the US administration did not meet Turkey's demand by not extraditing Fetullah Gülen, the coup attempt leader. Besides, the answer he gave to the question asked about the state of the emergency process being implemented is quite remarkable. Trump replied, "There is more than one civil rights problem in the US; we cannot deal with the citizenship rights of other countries without solving them." (Defne, et.al, 2018).

One of the problems between the US and Turkey is lifting Turkey's visas under the Muslim refugees' heading. Turkey reacted to such an attitude by not being silent about it. The visa crisis broke out between the two states. Turkey has been dramatically affected by the Trump administration's prejudiced behavior towards Muslims. Turkey did not remain silent against 
Trump's anti-Islam remarks (Simon, 2019).

Trump has clearly expressed his thoughts on the Middle East. To him, coups in the Middle Eastern countries cause instability. He accuses the George W. Bush and the Obama administrations of such instability in the Middle East. One of the crises between Turkey and Trump is that the US administration acted indirectly, not directly with the Assad administration. As Turkey will not support Assad, there will be conflict (Ozden, 2019).

While it is not sure what would happen with the president-elect Joe Biden at the time of writing this study, it is not possible to recover the relations between Turkey and the US if the Trump administration continues to support Assad regimes in the Middle East.

\subsection{MARCH 12003 MEMORANDUM}

The March 1 Memorandum period represents the tensest period in the history of Turkey-US relations. In this period, US President Bush asserted a pre-emptive strike doctrine as initiation of direct attack that is different from the deterrence and containment doctrines of the Cold War, by claiming to militarily attack any state that is believed to harbor nuclear, biological or chemical weapons of mass destruction or host terrorists, support international terrorism. It declared war on Iraq without the UN's support. The pre-emptive attack is an attack made by an opponent to destabilize his attack against the preparation of an attack, neutralize the attack, or take the initiative by taking the advantage over the enemy. In a pre-emptive attack, unlike a preventive attack, the aim of being the first to strike before a very imminent and inevitable conflict is in question. The US cited that Iraq was producing Weapons of Mass Destruction and that it had a relationship with the perpetrators of the 9/11 attack and claimed the Iraq invasion as a legitimate right to defend Iraq because it was preparing an attack against the US for such reasons. The US claimed that the threat from Iraq was very imminent and inevitable. Therefore, it sought to display the Iraq invasion as a pre- emptive attack and followed the repressive policies to support Turkey. However, while Turkey wanted the partnership between the parties as a memorandum text, the US administration wanted to enter Iraq as soon as possible without waiting for the UN resolution and had its soldiers wait in the Mediterranean memorandum process (Defne, et.al, 2018).

President Bush's fait accompli attitude towards Turkey arises from the strategic partnership understanding between the parties and the Turkish Government's fulfillment of such requests without any reservation. While negotiations were held in the Turkish Parliament, some US officials commented that many bilateral relations, especially IMF loans, will be adversely affected if the motion is not passed (Simon, 2019).

Turkey, the US's strategic partner, had a reserved approach towards the US's demand because it lost approximately 100 billion dollars during the Gulf War in 1991, and the US did not keep the promises it made. Turkey did not want to experience a similar crisis and hold an assured position and formalize the US's financial support before the memorandum.

Besides, Turkey's concerns are not only about minimizing the economic damage brought by the war and the federated Kurdish state created in the north of Iraq, but also collecting weapons distributed to the groups, Turkoman status, and fighting against the PKK. As the US authorities that abstain from creating an official memorandum noted that "Turkey seeks an additional financial aid." in their public, it paved the way for Turkey to be perceived as a country that uses alliance for money (Alex, 2019).

The memorandum process started in such a conjuncture. Although Turkish concerns were not fully met, the Prime Ministry memorandum concerning sending Turkish soldiers abroad and foreign armed forces to be present in Turkey was sent to the Turkish Parliament on February 25, 2003.

While it contained demands to meet the US's needs rather than Turkish needs and interests, it 
was sent to the Parliament despite technical, military, economic, and political reservations. However, it could not get the absolute majority vote, which was mandatory to be accepted, was rejected by 264 Yes, 250 No, 19 abstention votes on March 1, 2003 (Defne, et.al, 2018).

Following such a resolution, which was met wonderingly worldwide, it is revealed that the US and Turkey followed different security strategies and have a different understanding of the partnership model. However, Turkey kept its serious state attitude against peremptory and dismissive criticism of the US officials and sought not to deteriorate the bilateral relations. It also noted that it would continue its relations with the US in close contact and cooperation (Alex, 2019). Therefore, the failure to approve the March 1 memorandum reflects the democratic debate on military intervention in Iraq and is a turning point for the post 9/11 US-Turkish relations in the military dimension. While Turkey, an ally for removing weapons of mass destruction, has been in close contact and consultation with the United States, the US followed a reluctant foreign policy for cooperation and support in security dimensions following the March 1 memorandum. It indicated a shift from consent to coercion in Turkish-US relations (Ozden, 2019).

\subsection{HOOD EVENT}

Rejecting the memorandum prevented the US from intervening in Iraq from the north, which cost the US three trillion dollars in additional costs. Besides, oil prices rose following the dollar's significant depreciation, per heavy economic burden, the Republican Party lost the Senate elections, and the US Secretary of Defense changed (Simon, 2019).

Turkish-US relations, which acquired a different identity following the memorandum crisis, escalated extensively by the US raid to Turkish Special Forces outpost in Sulaymaniyah and taken to Baghdad hood over their heads July 4, 2003. The Turkish soldiers, who were taken into custody for 60 hours after the raid on the Special Forces Headquarters, were questioned, and it was announced that the operation carried out by the US Defense Minister was based on sensitive and reliable intelligence (Alex, 2019).

The operation mainly aims to prevent Turkey from establishing dominance in the region, force Turkey to withdraw from the northern part of Iraq, and liquidate the Turkoman front from Iraqi politics. However, assessing the event per our study reveals that the US operation was against the March 1 memorandum. US-Turkey relations' negative stance following 9/11 escalated tremendously following the Sulaymaniyah raid and led Turkey to question the alliance. Representing a significant NATO wing, rather than an ordinary ally, Turkey understood that it is alone in foreign policy. The reflections continued until the US left Iraq (Ozden, 2019).

\subsection{PKK TERROR}

Turkey's taking action against terrorist actions from Northern Iraq and eliminating them complies with rules of international law. Suppose there is no authority in a country to be held responsible for activities that harm another state, just as the principle of personal sovereignty applies in places not subject to any state's sovereignty. In that case, the victim country can stop problematic activities by its efforts (Simon, 2019).

The US's implicit support to the PKK with an ambivalent display due to some interests led to occasional tensions in relations. However, terrorism is a bleeding wound and political impasse for Turkey and weakens its precise foreign policy decision-making mechanism. Therefore, the US attitude towards the PKK is a sensitive issue to address in Turkish-US relations. The US has a vital role in developing and strengthening PKK terrorism for Turkey. Turkey is aware of the US contribution for not establishing a peaceful environment in Turkey and has a trust deficit against the US (Alex, 2019).

Aiming to solve the Middle East security problems via a strategic partnership with Turkey in the fastest and cost-effective manner, the US reveals that it moves away from a joint action and consensus, which contains political, commercial, 
economics and most importantly, foreign policy in security dimension with Turkey following September 11 and its stance against the PKK.

\subsection{TERROR THREAT IN THE TURKISH}

\section{STRAITS}

Following September 11, the concept of terrorism began to be defined in different dimensions worldwide, and accordingly, the risk perception of countries changed. The straits have pivotal importance for Turkey as the ships can pose risks. Besides, the possibility of using private passenger ships along with cargo ships for terrorism purposes makes it mandatory to increase the inspections and interventions. Per the 1936 Montreux Straits Convention, Turkey can control and search the vessels passing through Turkey's Bosphorus (Defne, et.al, 2018).

Similarly, the "Turkish Straits Maritime Traffic Regulation", which promulgated in 1998, regulates Turkey's identification of the ships' transit route to pass through the straits and ships to comply with applicable tonnage content rules in certain hours. Besides, such practices, aiming to minimize the terrorist threat, create a common security ground in the international arena with the allied US's support in foreign policy, have exceptions demanding that the system does not serve the US interest has caused debates on President Bush's security doctrine. Bush's fait accompli attitude towards Turkey arises from the strategic partnership understanding between the parties and the Turkish Government's fulfillment of such requests without any reservation (Simon, 2019).

\subsection{MAVI MARMARA CRISIS}

Starting its relations with Israel after the 1960s, Turkey is the first Muslim country to recognize Israel and developed bilateral relations by conducting military and economic agreements with Israel following the end of the Cold War. Both sides had very significant gains during the 1990s. However, they adopted different perspectives during the US intervention in Iraq and adopted different foreign policy attitudes.

Besides, Israel reacted to Turkey for supporting
Hamas, who wants to take on an active role in solving the ongoing war between Israel and Palestine, and the relations escalated between the two countries as they increase the dose of rhetoric in foreign policy. Israel conducted operations to the Mavi Marmara ship, which was moving towards Palestine for humanitarian purposes and had nine civilians onboard killed on May 31, 2010 (Defne, et.al, 2018).

This severe event has been the beginning of an essential process in Turkey-US relations. As Turkey was faced with Israel, yet another ally of the US in the Middle East, the UN made an emergency meeting and condemned Israel; however, the US pursued a passive attitude following this event.

The US wants to use Turkish Muslim identity in its new strategic and transformation objectives in the Middle East and ensure Turkey assumes a dominant role in solving the problems in countries like Egypt, Sudan, Pakistan, Israel, Syria, and Palestine, Iran, Iraq, Afghanistan. However, as Turkey could not get the US's political cooperation in the Mavi Marmara event in which Turkey expected concrete support, it reveals that the alliance's concept is a political discourse of the US politicians without any formal infrastructure (Alex, 2019).

\subsection{WIKILEAKS CRISIS}

The Wikileaks Crisis started when Julian Assange, a hacker-turned journalist-activist, published nearly 100,000 secret American documents on Afghanistan and Iraq on his website, caused many countries to face each other in the international community.

The published documents concerning Turkey are about the inability of border control, Iraqi citizens living in Turkey to Al-Qaeda, lack of competence of Erdoğan's inner circle and consultation services, and corruption related to such names. Besides, Wikileaks documents reveal that Ergenekon and Balyoz cases that discredit the Turkish Armed Forces in Turkey are regularly conveyed to the US (Simon, 2019).

Wikileaks documents have not led to a significant 
crisis in Turkey-US relations, on the contrary, the US made some statements to prevent trust deficit in its relations with Turkey, and Turkey avoided perceiving such documents as the official foreign policy of the US.

\subsection{ARMENIAN GENOCIDE CLAIMS}

Another critical problem in Turkish-American relations is the speech that each new US president will make at the US Congress on the first April 24 following his inauguration, regarding the Armenian genocide allegations. Both the Armenian Lobbies and the Turkish Governments closely follow such statements as the Armenian Lobbies put pressure on the US administration to accept the events of 1915 as genocide and support the presidential candidates during the election campaigns (Defne, et.al, 2018).

US eyes for a roadmap that will not damage the partnership relations with ally Turkey. However, it takes some steps to get the support of the Armenian Lobbies to the detriment of Turkey. During the Clinton presidency, the draft entitled "Education and Commemoration Resolution on the Armenian Genocide" was brought to the Parliament. The events described as "massacres" were asked to be called "genocide" with this draft. It was withdrawn from the Parliament at Clinton's request considering the issues in the Middle East (Simon, 2019).

President Obama's April 24 speech was followed closely in Turkey and Israel. Noting that he supports the Armenian claims during his election campaign, Obama used the "medsyeghem" expression, which refers to "major disaster" in his speech. Turkey reacted to the change of speech date from April 24 to April 23 with ever-changing conceptual content and noted that it is due to internal political concerns (Alex, 2019).

Besides, Armenians, another society that was not satisfied with the statement made, reacted by sending a message that President Obama did not keep his promise during the election period.

In summary, the so-called Armenian genocide allegations have always been used as a US policy tool. It is used as a trump card against Turkey in foreign policy and utilized in domestic policy to support the Armenian lobbies. Therefore, the US damages the model partnership relations with its ally Turkey as it did not take a clear stance (Simon, 2019).

\subsection{EXTRADITION}

Turkey witnessed FETO Terrorist Organization's action, which attempted a coup, by using its infiltrated elements in the Government on July 15, 2016. It brought the extradition of criminals in the US to the public agenda. Per the legal framework for the extradition of criminals between the two countries is constituted by the "Treaty on Extradition and Mutual Judicial Assistance in Criminal Matters", which is entered into force on January 1, 1981 (Ozden, 2019).

Following July 15, Turkey demands the extradition of ringleader Gulen, living in the US. However, the US demonstrated again that it does not share the sensitivity of alliance with Turkey to fight against terrorism with its non-extradition resolution.

Besides, the crisis on extradition was not limited to it. Pastor Brunson was arrested in Izmir on charges of affiliation with FETO and PKK terrorist organizations and espionage, after which a house arrest measure was imposed on July 7, 2016. However, Evangelists' support of the Republican Party and President Trump in the US elections has made Pastor Brunson, a member of this church, a political maneuver. Therefore, the US administration, which successively stated for the release of Pastor Brunson, also acquired a political trump in the same period due to the trial of Hakan Atilla, the former Deputy General Manager of Halk Bank, in the case held with the allegation that the embargo on Iran was violated (Alex, 2019).

While Brunson was released following a trial, the statement against diplomatic practices and unilateral sanctions against the Turkish economy left Turkey in a difficult situation and made the Brunson case a political case ${ }^{139}$. Acting reluctant for economic privilege or convenience by the US to Turkey and applying additional quota and high 
tariffs to Turkey, which frequently experiences an economic crisis, and using the economy as a political tool to influence Turkish Foreign Policy to demonstrate that the US moves away from joint action and consensus with Turkey (Ozden, 2019).

\subsection{S-400 CRISIS}

For many years, Turkey's pursuit for an air defense system resulted in Russia's memorandum in 2019. Per the memorandum, the first part of the S-400 air defense system was delivered to Turkey on July 12, 2019. Thus, Turkey has taken a deterrent step against the risks arising. Thanks to the activation of S-400, Turkey would have a significant military capacity against tensions in Syria, East Mediterranean, and US-Iran (Kibaroglu, 2019).

The S-400 air defense system is an advantageous air defense system developed against Western tactical bombers such as F-16, F-15, F-18, F-35, ballistic missiles, cruise missiles, and unmanned aerial vehicles. Therefore, Turkey having the S400 air defensive systems makes it possible to declare a no-fly zone in Northern Iraq, Northern Syria, or elsewhere. However, this memorandum will improve mutual dependence relations. In this context, Turkey-Russia relations will not be limited only by the sale of S-400 and improve in military, economic, and political sphere rapidly (Turkmen, 2019).

The US interpreted Turkey's supply of air defense system from Russia as a departure from the Atlantic system and trajectory, thereby stopping the delivery of F-35 aircraft, which the US produced and sold earlier. Besides, per the US, the S-400 missile systems allow Russian engineers to monitor and learn US-made F-35 aircraft maneuvers. The S-400 missile defense system's delivery made the Turkish-US relations into a political crisis again, assuming that it would harm the national security interests of the US and NATO (Kibaroglu, 2019).

In this context, several US security agencies objected to the S-400 acquisition. Shanahan, the former deputy Defense Minister, expressed sanctions against Turkey in the S-400 acquisition in a letter on June 6, 2019. In other words, it officially declared that Turkey must choose between S-400 and F-35 with this letter. However, while S-400 meets an essential Turkey requirement, Turkey's removal from F-35 is a danger that would affect its NATO membership and military capacity in terms of defense power (Alex, 2019).

Turkey's fundamental approach is to exit from such a dilemma and eliminate the US over the $\mathrm{S}$ 400 air defense system in Turkey and remain in the F-35 program. If this strategy works, Turkey will both have S-400 and partner and owner of F35 fighter jets and have a maximum benefit of ${ }^{144}$. However, it is clear that Turkey's having such two strategic weapons would be opposed by the US or other regional actors because such two strategic weapons carry Turkey's defense capability to an asymmetrical level (Kibaroglu, 2019).

While the crisis has dragged the US-Turkey relations into a tense period again, President Trump was reluctant to apply severe sanctions against Turkey due to the S-400 acquisition in his statement at the G20 summit. The idea of preventing the Middle East developments from turning into a crisis is the most critical rapprochement source between the two countries in this period. The modus operandi of the US, which unilaterally uses pre-emptive and preventive war strategies as the hegemonic power in the international system in a period when Turkey's national security is under a severe threat due to the increasing terror, intervention in Syria, cross-border operations, is reflected on the Turkish-US relations. The understanding of the partnership between security and cooperation has been transformed into unilateral oppressive policies of the US (Alex, 2019).

\section{CONCLUSION}

March 1, 2003, and post 9/11 were significant milestones in Turkish-US relations' security and cooperation, which we included in this study. US declared war against Iraq without the UN's support per the pre-emptive war doctrine and 
pursuit a repressive policy to have the support of Turkey in this war. Bush's fait accompli attitude towards Turkey arises from the strategic partnership understanding between the parties and the Turkish Government's fulfillment of such requests without any reservation. However, the memorandum, which was voted on March 1, 2003, could not get the absolute majority vote, which was required to be accepted. The strategic partnership process, which was not filled and based on the US's unilateral action, ended. However, as Turkey could not get the US's political cooperation against PKK and Northern Iraq and Turkey expected concrete support, it reveals that the alliance's concept is a political discourse of the US politicians without any formal infrastructure (Simon, 2019).

Aiming to fill the gap that remains from the USSR with the end of the Cold War in the fastest and most cost-effective way with a strategic partnership with Turkey, which has religious, ethnic, historical, and cultural bonds in the region, the US reveals that it moves away from a joint action and consensus, which contains political, commercial, economics and most importantly foreign policy in security dimension, filled the infrastructure of partnership concept. The relations were adversely affected due to the Sulaymaniyah Raid. Besides, considering the strategic partnership elements in US-Turkish relations, there are no extensive economic relations, has low trade volume, the US acting reluctant for an economic privilege or convenience to Turkey and applying additional quota and high tariffs to Turkey, which frequently experiences an economic crisis, and using the economy as a political tool to influence Turkish Foreign Policy.

The US has changed its strategic objectives for the Middle East during the Obama administration, and US-Turkish relations evolved into a model on religious freedom, human rights, the rule of law, democracy, common ideal, and values of the two countries with such change. Obama's model partnership doctrine reveals itself as a new attitude for Turkey that it is ready to listen to and assess the other party's suggestions and opinions and expresses that it has a vision and voice breaking off narrow visions. Therefore, this model creates a partnership understanding based on the common ideals and values of the two countries, such as freedom of belief, human rights, the rule of law, and democracy, which is not limited to cooperation in security matters. The US's new strategic and transformation goals for the Middle East greatly influence this partnership. The US wants to use Turkish Muslim identity and ensures Turkey assumes a dominant role in solving the problems in countries such as Egypt, Sudan, Pakistan, Israel, Syria, Palestine, Iran, Iraq, and Afghanistan. Such that the function provided by the US to Turkey has gained significance when it merges with Turkey's desire to be a model between the West and Islam geography and has been an indispensable tool for US Middle East strategy. Therefore, the process that started with the memorandum crisis between the two countries during the Bush period and created a mutual trust problem was overcome with Obama's administration (Simon, 2019). The relations between the two countries turned into full cooperation in the tense process in the Middle East.

Moreover, Turkey's Incirlik Air Base for the US withdrawal from Iraq and the logistical support provided by the Mersin Port has strengthened the mutual trust relationship and, it is converged over the ideas of Middle East developments to avoid turning into a crisis. However, Turkey was faced with Israel, yet another ally of the US in the Middle East, due to the Mavi Marmara event and could not find the US's political support.

Even though the tension between the two countries has risen, with events during the Trump administration such as the extradition, the trial of Pastor Brunson, the purchase of the S-400 from Russia, and the US statement on stopping the delivery of F35 aircraft, Turkish and US cooperation and partnership would improve if they respect their territorial integrity, regime, and 
essence with peaceful policies.

It is clear that the US and Turkey, which share common interests in specific issues, would strive to deteriorate the partnership in an international arena. Turkey's strengthening political stance and being a model state in the Middle East is a significant opportunity. Turkey's national security is under a severe threat due to the increasing terror, intervention in Syria, cross-border operations. The US, which unilaterally uses preemptive and preventive war strategies as the international system's hegemonic power, does not support Turkey's fight against terror enough. Accordingly, the US's efforts to find a solution to the PKK problem and prevent terrorism financing will create a radical, positive, and optimistic solution for security and cooperation in the following years of the relationship between them.

\section{REFERENCES:}

[1] ACAR Ü. and URHAL O. (2007). Devlet, Güvenlik, Istihbarat, Terörizm, Adalet

a. Yayınevi

[2] ALEX W. (2019). How America's relationship with Turkey fell apart, Available from: https://www.vox.com/world/2019/4/11/18 292070/usa-turkey-trump-erdogan-s400

[3] ARAS, B. and BACIK G. (2007). 11 Eylül Öncesi ve Sonrast. Etkileşim

[4] Yayınlar1,

[5] ARI, T. (2004). Irak, Iran ve ABD, Alfa Yayınları.

[6] BARAN, Z. (2005). "The State of the U.S.-TurkeyRelations," House Committee on International Relations, Subcommittee on Europe andEmergingThreats.

[7] BARNETT, T. (2005). Pentagon'un Yeni Haritası. Translation: Cem KÜÇÜK, 1001 Kitap Yayınları.

[8] BOZKURT, E. (2003). Birleşmiş Milletler Sisteminde Kuvvet Kullanımı Körfez Krizi
[9] Örneği ve Irak'ın Durumu ABD'ye 11 Eylül Terörist Saldırısı. Nobel

[10] Yayınları.

[11] BUZAN, B. (1998). Security: A New Framework for Analysis. London, LynneRiennerPublishers, Boulder.

[12] CAŞIN, M. H. (2007). Küreselleşmenin Avrupa Birliği Ortak Güvenlik ve

[13] Savunma Politikasina Etkisi, Nokta Kitap.

[14] CHOMSKY, N. (2001), 11 Eylül, Çev. Dost KÖRPE, Om Yayınevi.

[15] ÇAKMAK, C. (2005). “Türkiye-ABD İlişkilerinde Stratejik Ortaklık", Stratejik

[16] Öngörü Dergisi, Tasam Yayınları, Y.2, N.5.

[17] DEFNE A., PINAR D. and GRADY W. (2018). US-Turkey Relations: From Alliance to Crisis. Available from: https://www.atlanticcouncil.org/blogs/newatlanticist/usturkey-relations-fromalliance-to-crisis

[18] DEMIRKIRAN, Ö. (2005). Soğuk Savaş Sonrasi Ortadoğu Ekseninde TürkAmerikan

[19] İlişkileri, Süleyman Demirel Üniversitesi Sosyal Bilimler Enstitüsü Yüksek Lisans Tezi.

[20] DİLMAÇ, S., ERKAN, M. (2006) Devlet Güvenliği Terörizm ve Istihbarat.

[21] Ankara Emniyet Genel Müdürlüğü Yayınlar1, Ankara.

[22] DÖNMEZ, S. (2010). Güvenlik Anlayışının Dönüşümü: İttifak Kavramı ve NATO, Marmara Üniversitesi Sosyal Bilimler Enstitüsü Yayınlanmamış Doktora Tezi

[23] FRİEDMAN, G. (2009). Gelecek $100 \mathrm{Yll}$. Translation: İbrahim Şener ve Enver Günsel, Pegasus Yayınları.

[24] GORDON, P. and TAŞPINAR Ö. (2009). Türkiye'yi Kazanmak: Türkiye Batı İcin

[25] Neden Vazgeçilmez, Translation: Metin Okur. Timaş Yayınları, p.147. 
[26] İNAT, K. (2004). ABD'nin Haydut Devletleri. Değişim Yayınları.

[27] KANAT, S. (2005). Terörizm, Insan Haklarl, Güvenlik: 11 Eylül Sonrası Meydana

[28] Gelen Değişiklikler. Yüksek Lisans Tezi, Süleyman Demirel

[29] Üniversitesi.

[30] KİBAROĞLU, M. (2019). “Türkiye'nin S-400 Macerasının 4 Yüzü”. Yörünge.

[31] KİRIŞÇİ, K. (2000). USTurkishRelations: From Uncertainty To Closerties.

[32] InsightTurkey, Vol.2, No:4

[33] KISSINGER, H. (2000)/ Diplomasi Translation: İbrahim Kurt. Türkiye İş Bankası Kültür Yayınları.

[34] KRZYSZTOF, S. and ANDRZEJ, W. (2019). The S-400 for Turkey. The crisis in Turkish-American relations escalates, Available from: https://www.osw.waw.pl/en/publikacje/os w-commentary/2019-06-12/s-400turkeycrisis-turkish-american-relationsescalates

[35] ORDAF Araştırma Grubu. (2018). "Rahip Brunson Davası: Türkiye-ABD İlişkilerinin Çıkmazı”, Durum Değerlendirmesi.

[36] OMER, G. I. (2005). An Analysis of Turkish-American Relations from 1945 to 2004. Initiatives and Reactions in Turkish Foreign Policy, Turkish Journal of International Relations- Alternatives, Volume 4, number3. Available from: https://dergipark.org.tr/download/articlefile/19464.

[37] ÖZDAĞ ,U. (2003). "Irak'ta Amerikan ve Türk Politikaları", Avrasya-Bir Vakf , Asam

[38] Yayınları, Asam Çalışması, N.2.

[39] ÖZDEN, Z. O. (2019). US-Turkey Relations in the Trump Era: A Turkish Perspective, available from: https://thenewturkey.org/us-turkey- relations-in-thetrump-era-a-turkishperspective.

[40] ÖZPEK, B. (2012). 11 Eylül Sonras1 Ortadoğu. Ortadoğu Etütleri, V.3, N.2,

[41] PEHLIVAN, B. and TERKOĞLU, B. (2012), Wikileaks'te Ünlü Türkler. Kırmızı Kedi Yayınevi.

[42] SAE (Stratejik Araştırmalar Enstitüsü). (2009). “ABD ile İlişkilerde Yeni Dönem: Model Ortaklık". April Volume

[43] SIMON, W. (2019). The new era of USTurkey relations is defined by difference, not common goals, Available from: https://www.thenational.ae/opinion/comm ent/the-new-era-of-us-turkey-relationsisdefined-by-difference-not-commongoals-1.888840.

[44] TÜRKMEN, F. (2012). Türkiye ABD İlişkileri. Timaş Yayınları.

[45] WHELAN, R. (2006). El-Kaidecilik Islam'a Tehdit, Dünya'ya Tehdit. Translation: Hüseyin BAĞCI. Platin Yayınları.

[46] KURT, V. (2019). "S-400 ve F-35 Denklemi”. SETA Analiz, p.291

[47] YENIÇERİ, Ö. (2002). Terör ve ABD: Terörün Hegemonya Sorunu Olarak

[48] Kullanılması Sorunu". 2023 Dergisi

[49] YILMAZ, S. (2002). Güçsüz Güç. Güvenlik Stratejileri Dergisi. V.3, N.5. 